research after the 14-day limit, will be a criminal offence, punishable with a jail sentence of up to two years. So why the relief? Because there had seemed a danger that the House of Lords would choose the other option offered by the government, and opt for a ban on all research with embryos.

The Embryo Bill gives effect to the recommendations in 1984 of the Warnock Committee on embryo research, the practice of in vitro fertilization (IVF) and related matters. The bill, of course, is shockingly late. When it is generally acknowledged that public anxiety will be quietened only if people know what researchers are doing and understand why, regulation has fallen to a committee organized by the Medical Research Council and the Royal College of Obstetricians and Gynaecologists whose intervention rests on the voluntary compliance of researchers and practitioners. The committee has done an excellent job, but will also be relieved that the end of its tenure of a non-statutory office is in sight. But even now, the issue is not settled. The House of Lords still has to pick over the details. Only then, a couple of months from now, will the House of Commons have its say.

Delight at the House of Lords decision notwithstanding, it is relevant that the bill as it stands is deficient in many ways, not least because of the 14-day limit on research with human embryos. Not that there is at present any great push for laboratory work that would breach the limit. Most proposals to the voluntary committee are intended to improve the effectiveness of IVF for the treatment of infertility. Otherwise, for the general understanding of early embryonic development, people seem content to work with mice or other species. But the time will come when Warnock's arbitrary choice of 14 days, an estimate of the appearance in the developing embryo of the primitive streak from which nerve tissue emerges, will impede research of potential value. It would have been better to have provided the licensing authority with more explicit statutory guidelines and then to have done without a limit.

There is a wider reason for regretting this feature of the bill. The 14-day limit will be generally understood to offer absolute protection to embryos older than 14 days. But if embryos are protected after 14 days, why should it be permissible to abort fetuses after 28 weeks of gestation (the present time-limit, likely to be reduced)?

Dr John Habgood, the Anglican Archbishop of York, did a manful job in last week's debate by arguing that the moral questions that apply to embryo research and abortion are distinct. Nobody can deny that. Research with embryos promises understanding that will be generally beneficial, abortion (under the present British law) protects the health and social well-being of individual women - large numbers of them every year. The obvious difficulty is that this will not be generally appreciated and that, when it is, the moral case for embryo research will seem the stronger. In short, whatever happens to the Embryo Bill, the 14-day limit is a dangerous hostage given to fortune.

\section{Animals and friends}

The US Congress should avoid passing unworkable animal rights legislation.

THE US Congress seems to be awakening to the need that something should be done about the animal rights movement, but only slowly (see page 580). The diffidence is understandable. Over the past decade, advocates of animal rights have won a dubious but formidable reputation for implacable ferocity. In the circumstances, it is remarkable that three members of the Congress have been brave enough to put their heads above the parapet, introducing bills directed against those who perpetrate crimes against laboratories and against those who work in them. Whether the zealots responsible will be deterred by knowing that breaking into federally supported laboratories may in future be a federal felony, or that they may have the FBI on their tails, is another matter. The stockin-trade of those that perpetrate violence on behalf of animals is the determination not to compromise with reality.

That is why the Congress would be better advised to concentrate its energies on more manageable objectives. For the past five years, the Animal Welfare Act has been lumbered with a welter of provisions whose full implications are not yet clear - except that they cost money but which may be in part unworkable. That people embarking on experiments with animals should be required by the act to justify what they intend to an independent panel is not unreasonable. In Britain, researchers have been required for two years to win approval from a government committee (just reconstituted, with Lord Nathan as chairman) and appear not to find the process over-irksome. But in the present climate, the US legislation almost guarantees that the committees become vehicles for rehearsing irreconcilable opinions. The objectives of animal welfare, meanwhile, are overambitiously defined. The act needs urgent attention to be made workable.

For the rest, very little can be expected of the Congress. The US administration, the most generous supporter of biomedical research, could be more outspoken in defence of its own spending programme, but there are few votes in that.

Much the most serious burden rests with the scientific community, which should concentrate on one central task: persuading moderate opinion that the use made of animals in research is responsible, humane and directed at goals considered by the generality to be worthwhile. But what purpose will be served by placating moderate opinion, when the men and women with crowbars and spray-cans are incorrigible? Because the wild men, despite the incoherence of their cause, derive their strength from the indifference of moderate opinion to the harm that will be done if biomedical research is made impossible. 